\title{
АНАЛИЗ ГЕОЛОГИЧЕСКИХ ОБРАЗЦОВ МЕТОДОМ МАСС-СПЕКТРОМЕТРИИ С ИНДУКТИВНО-СВЯЗАННОЙ ПЛАЗМОЙ: ОСОБЕННОСТИ ПРОБОПОДГОТОВКИ И ГРАДУИРОВКИ
}

Николаева И.В., Палесский С.В., Козьменко О.А., Кравченко А.А.

ФГБУН Институт геологии и минералогии им. В.С. Соболева СО РАН, Новосибирск, Россия

inikol@igm.nsc.ru

DOI: 10.26902/ASFE-11_15

Массовое использование в практике геохимических исследований высокочувствительного метода - масс-спектрометрии с индуктивно-связанной плазмой (МС-ИСП) - позволяет существенно расширить возможности элементного анализа за счет одновременного определения почти всех химических элементов (изотопов) с диапазоном концентраций до 9 порядков в рамках одного измерения. При этом возникает необходимость развития новых оригинальных методик пробоподготовки геологических образцов, обеспечивающих полное переведение в раствор элементов с разными химическими свойствами, стабильность анализируемого раствора и максимальное снижение в нем содержания матричных элементов.

В работе проведено сравнение разных способов пробоподготовки геологических образцов для МС-ИСП анализа - открытое и микроволновое кислотное разложение, сплавление с метаборатом лития с переведением плава в раствор, а также использование для лазерной абляции (ЛА) готовых стекол после рентгено-флюоресцентного анализа (РФА) без дополнительной пробоподготовки. На основании полученных результатов сделан вывод о преимуществах и недостатках каждого способа пробоподготовки. Выбор наиболее оптимального подхода определяется как набором интересующих элементов, так и химико-минералогическими свойствами анализируемых образцов.

Многоэлементный анализ выполнен с учетом возможных спектральных наложений в необходимом для каждого изотопа разрешении (низком, среднем или высоком) на массспектрометре высокого разрешения ELEMENT Finnigan MAT как в растворах после разложения геологических образцов, так и в стёклах с помощью ЛА на установках с ультрафиолетовым лазером Nd:YAG (длина волны - 213 и 266 нм).

Для снижения погрешности элементного МС-ИСП анализа на стадии измерений изучена возможность использования для внешней градуировки разных градуировочных стандартов - многоэлементных эталонных растворов с добавлением и без добавления основных матричных элементов, искусственных стекол известного состава NIST-610-614 и стандартных геологических образцов, приготовленных аналогичным способом, что и анализируемые образцы, в сочетании с внутренним стандартом.

Применение для градуировки наиболее полно и точно аттестованных стандартных геологических образцов вместо эталонных растворов и синтетических стекол позволяет снизить матричное влияние при определении основных и примесных элементов в сложных геологических матрицах.

Правильность разработанных МС-ИСП методик подтверждена сравнением результатов, полученных для международных и отечественных стандартных образцов состава естественных горных пород с аттестованными (рекомендованными) величинами, а также сопоставлением результатов анализа природных образцов с данными независимых методов - РФА, РФА с синхротронным излучением и термоионизационной массспектрометрии.

Разработанные методики МС-ИСП и МС-ИСП с ЛА широко применяются в аналитической практике ЦКП многоэлементных и изотопных исследований СО РАН. 